\title{
Effect of time of application of spent oil on the growth and performance of maize (Zea mays)
}

\author{
Kelechi L. Njoku*, Modupe O. Akinola and Temitope O. Busari \\ Department of Cell Biology and Genetics, University of Lagos, Nigeria. \\ Accepted 18 December, 2011
}

\begin{abstract}
The effect of spent oil pollution on the growth and performance of Zea mays at different stages of growth was investigated in this study. It involved addition of different quantities of spent oil to soils where Zea mays plants at different stages of growth were growing on. The plants showed differential response to quantities of spent oil added to the soils and the times of application. Plants exposed to spent oil pollution one week after germination had the highest level of growth inhibition and the highest chlorophyll content. The leaf area development of the plant was inhibited by the exposure of the plant to spent oil pollution as observed seven weeks after germination. The application of spent oil to the soils three and five weeks, respectively after the germination of the seeds of $Z$. mays had similar effects on dry matter accumulation of the plant. Statistical differences occur on the growth and performance of the plants exposure to spent oil pollution at different stages of growth $(p<0.05, p<0.01$ and $p<0.001)$. The results from this study showed that generally $Z$. mays may suffer greater inhibition of growth and performed poorly when it is exposed to spent oil pollution at tender stage of growth.
\end{abstract}

Key words: Spent oil, time application, growth, performance, Zea mays.

\section{INTRODUCTION}

Various studies have reported the adverse effect of petroleum products on plants ranging from reduced germination of seeds, reduced survival of plants to reduced yield of plants (Akinola et al., 2004; Andrade et al., 2004). Most of the reports on the effects of petroleum products on plants have focused on crude oil, diesel and gasoline (Siddiqui and Adams, 2002; Inoni et al., 2006) which get to the environment through accidental spillage. However, through the activities of automobile, generator, other machines, and servicing engineers (mechanics) spent oil is discharged to the environment indiscriminately.

Spent engine oil here refers to used motor oil collected from mechanical/automobile, workshops, garages, and industry sources like hydraulics oil, turbine oils, process oil and metal working fluids (Olugboji and Ogunwole, 2008). Spent oil is produced when new mineral-based crankcase is subjected to high temperature high

\footnotetext{
${ }^{\star}$ Corresponding author. E-mail: kecynjoku@gmail.com. Tel: +2348033842956 .
}

mechanical strain (ATSDR, 1997). Spent oil is a mixture of different chemicals (Wang et al., 2000) including petroleum hydrocarbons, chlorinated biphenyls, chlorodibenzofurans, lubricative additives, decomposition products and heavy metals that come from engine parts as they wear away (ATSDR, 1997). Spent oil contains polycyclic aromatic hydrocarbons (PAHs) and chemical additives like lead, zinc, sulphur, phosphorus, magnesium, iron, vanadium, aluminum, nickel, calcium, barium, phenols, amines and benzenes (Meinz, 1999). The concentration of PAHs in spent oil increases with time of usage (Vwioko and Fashemi, 2005).

Spent oil is usually obtained after servicing and subsequent draining from automobile and generator engines (Sharifi et al., 2007). Spent oil is a common and toxic environmental contaminant not naturally found in the environment (Dominguez-Rosado and Pichtel, 2004). It gets to the environment due to discharge by motor and generator mechanics (Odjegba and Sadiq, 2002) and from the exhaust system during engine use and due to engine leaks (Anoliefo and Edegai, 2000; Osubor and Anoliefo, 2003). Also the discharge of spent oil to the environment takes place when plants are at different 
Table 1. The shoot length $(\mathrm{cm})$ of maize seedlings treated with different amounts of spent oil at their different times of growth.

\begin{tabular}{lccccc}
\hline Treatment days & Control & $\mathbf{5 ~} \mathbf{~ l}$ & $\mathbf{1 0} \mathbf{~ m l}$ & $\mathbf{1 5} \mathbf{~ m l}$ & $\mathbf{2 0} \mathbf{~ m l}$ \\
\hline Week 1 & $98.00 \pm 4.19$ & $75.57 \pm 1.23$ & $69.80 \pm 1.85$ & $44.67 \pm 22.34$ & $42.37 \pm 21.18$ \\
Week 3 & $98.00 \pm 4.19$ & $78.13 \pm 0.55$ & $74.53 \pm 0.38$ & $70.83 \pm 0.77$ & $67.87 \pm 0.75$ \\
Week 5 & $98.00 \pm 4.19$ & $80.50 \pm 1.31$ & $76.70 \pm 0.60$ & $73.467 \pm 0.52$ & $69.23 \pm 1.27$ \\
Week 7 & $98.00 \pm 4.19$ & $76.37 \pm 1.78$ & $68.50 \pm 2.22$ & $60.400 \pm 5.82$ & $56.03 \pm 7.05$ \\
\hline
\end{tabular}

stages of growth.

The disposal of spent oil into open vacant plots and farms, gutters and water drains is an environmental risk (Odjegba and Sadiq, 2002). Since spent oil is liquid, it easily migrates into the environment and eventually pollutes either water or soil (Olugboji and Ogunwole, 2008). Contamination of soils with spent oil leads to significant reduction of soil moisture (Akoachere et al., 2008). Spent oil significantly inhibits the activities of soil catalase and dehydrogenase (Achuba and PeretiemoClarke, 2007). Spent oil delays germination of seeds and causes reduction in the growth of plants (Adenipekun et al., 2008). The PAHs in spent oil have been shown to have indirect secondary effects like disruption of plantwater-air relationship (Renault et al., 2000) and effects on microorganisms like mycorrhizal fungi (Nicolotti and Egli, 1998).

The disposal of spent oil on farm land can take place when the crops grown on such land are at their different stages of growth. Plants are known to respond differently to their environment at their different stages of growth. It therefore became necessary to study what the effect of disposal of spent oil into the environment will have on the growth and performance of crops with time. This was done in this study using Zea mays as the test plant. Findings obtained in this study will help to guide people in knowing the harmful effect of discharging spent oil on farmlands. As such, farmers will know the stage of the plant growth when it is absolutely necessary to avoid spent oil discharge on farmlands. Such will help to reduce poor yield of crops associated with spent oil spillage.

\section{METHODOLOGY}

A total of fifty one buckets each filled with $4000 \mathrm{~g}$ of loam soil obtained from the Biological Garden of the University of Lagos were used for this study. Three of the buckets were used for control studies and were not polluted with spent oil while the others were divided into four groups. Each group was subdivided into four subgroups with each subgroup containing three buckets. Each group represented a period of application of spent oil while each subgroup represented a volume of spent oil added to the soil. The spent oil was applied at week 1, 3, 5 and 7 after germination of the seeds of the test plant while the quantities of spent oil applied are 5 , 10,15 and $20 \mathrm{ml}$.

The plants samples from each bucket were obtained two weeks after the 7th week application of the spent oil by carefully uprooting one plant from each bucket. The shoot length, dry matter content, leaf area and chlorophyll content of the uprooted plant samples were determined. The shoot length was determined by measuring the plants from the base of each plant to the tip while the dry matter content was determined as was described by Merkl et al. (2004). Plant samples were oven dried at $60^{\circ} \mathrm{C}$ to constant weight for $24 \mathrm{~h}$ after which the weights of the dry samples were determined using a sensitive weighing balance (Acculab-USA VIC 300 Model). The leaf area was determined as was described by Pearcy et al. (1989) after measuring the length of the longest part of the leaf and the width of the widest part of leaf by using the formula $0.5 \times L \times B(L=$ length and $\mathrm{B}=$ breadth). The chlorophyll content of the plant was determined using the method of Heidcamp (2003). It involved the extraction of the chlorophyll of $1 \mathrm{~g}$ of each leaf with $10 \mathrm{ml}$ of $80 \%$ acetone. The optical density (OD) of each extract was read off at $652 \mathrm{~nm}$ using spectrophotometer. The chlorophyll content $(\mathrm{mg} / \mathrm{l})$ of each leaf was determined by dividing the OD reading with 34.5 (Heidcamp, 2003).

The data obtained for the different parameters were statistically analyzed using Graphpad prism 4.0 software. This was done to determine the impact of the different quantities of spent oil applied to the plants and also the impact of the different times of application of the spent oil on the plant. These were done at 5,1 and $0.1 \%$ levels of significance.

\section{RESULTS}

The shoot lengths of maize seedlings exposed to different amount of spent oil at different points of growth are shown in Table 1. The shoot length of the plant treated with $10 \mathrm{mls}$ of spent oil at the first and seventh weeks was significantly shorter than the shoot length of the plant from the control treatment $(\mathrm{P}<0.01)$ at same period. Treatment of the seedlings with $15 \mathrm{ml}$ spent oil at first and seventh weeks of growth led significantly shorter shoot than the control treatment at the same period $(P<0.001 ; P<0.01)$. At all weeks of application, $20 \mathrm{ml}$ treatment led to significant reduction of the shoot length of maize $(P<0.05 ; P<0.01 ; P<0.001)$. Plants treated with 15 and $20 \mathrm{ml}$ spent oil were also significantly shorter than those with $5 \mathrm{ml}$ spent oil at one week after germination $(P<0.05)$. The dry matter content the plant was significantly affected by the quantity of spent oil added to the soil $(P<0.05,0.01,0.001)$ as shown in Table 2 . Application of 15 and $20 \mathrm{ml}$ of spent oil led to significant reduction of the dry matter content of maize $(P<0.05$, $\mathrm{P}<0.01 ; \mathrm{P}<0.001)$ at all weeks of treatment. $10 \mathrm{ml}$ treatment significantly reduced the dry matter content of maize $(P<0.01)$ only when it was applied seven weeks after the germination of the seeds. Significant differences were also observed in the dry matter content of maize treated with different quantities of spent oil at the different weeks of application. For the dry matter of the maize 
Table 2. The Dry weight of maize seedlings treated with different amounts of spent oil at their different times of growth.

\begin{tabular}{lccccc}
\hline Treatment days & Control & $\mathbf{5 ~} \mathbf{~ I ~}$ & $\mathbf{1 0 ~} \mathbf{~ I ~}$ & $\mathbf{1 5} \mathbf{~} \mathbf{l}$ & $\mathbf{2 0} \mathbf{~ m l}$ \\
\hline Week 1 & $0.903 \pm 0.05$ & $0.713 \pm 0.06$ & $0.630 \pm 0.09$ & $0.310 \pm 0.16$ & $0.407 \pm 0.20$ \\
Week 3 & $0.903 \pm 0.05$ & $0.850 \pm 0.03$ & $0.770 \pm 0.10$ & $0.550 \pm 0.09$ & $0.463 \pm 0.03$ \\
Week 5 & $0.903 \pm 0.05$ & $0.867 \pm 0.03$ & $0.803 \pm 0.07$ & $0.560 \pm 0.04$ & $0.420 \pm 0.15$ \\
Week 7 & $0.903 \pm 0.05$ & $0.653 \pm 0.07$ & $0.440 \pm 0.07$ & $0.390 \pm 0.05$ & $0.283 \pm 0.06$ \\
\hline
\end{tabular}

Table 3. The Leaf area $\left(\mathrm{cm}^{2}\right)$ of maize seedlings treated with various amounts of spent oil at their different times of growth.

\begin{tabular}{lccccc}
\hline Treatment days & Control & $\mathbf{5 ~} \mathbf{~ m ~}$ & $\mathbf{1 0} \mathbf{~} \mathbf{l}$ & $\mathbf{1 5} \mathbf{~} \mathbf{l}$ & $\mathbf{2 0} \mathbf{~ m l}$ \\
\hline Week 1 & $134.867 \pm 9.193$ & $113.87 \pm 2.20$ & $106.17 \pm 9.74$ & $65.53 \pm 33.46$ & $54.87 \pm 27.44$ \\
Week 3 & $134.867 \pm 9.193$ & $107.40 \pm 3.72$ & $101.20 \pm 8.10$ & $82.93 \pm 9.69$ & $77.00 \pm 4.08$ \\
Week 5 & $134.867 \pm 9.193$ & $116.67 \pm 4.39$ & $109.37 \pm 2.24$ & $104.37 \pm 1.15$ & $94.20 \pm 6.40$ \\
Week 7 & $134.867 \pm 9.193$ & $103.93 \pm 6.53$ & $105.20 \pm 12.19$ & $70.10 \pm 5.49$ & $69.07 \pm 10.61$ \\
\hline
\end{tabular}

Table 4. The chlorophyll content $(\mu \mathrm{g} / \mathrm{g})$ of the leaves of maize seedlings treated with various amounts of spent oil at their different times of growth.

\begin{tabular}{lccccc}
\hline Treatment days & Control & $\mathbf{5 ~} \mathbf{~ m ~}$ & $\mathbf{1 0} \mathbf{~ m l}$ & $\mathbf{1 5} \mathbf{~ m l}$ & $\mathbf{2 0} \mathbf{~} \mathbf{l}$ \\
\hline Week 1 & $0.043 \pm 0.009$ & $0.034 \pm 0.001$ & $0.030 \pm 0.002$ & $0.019 \pm 0.009$ & $0.007 \pm 0.003$ \\
Week 3 & $0.043 \pm 0.009$ & $0.032 \pm 0.004$ & $0.027 \pm 0.002$ & $0.025 \pm 0.001$ & $0.017 \pm 0.001$ \\
Week 5 & $0.043 \pm 0.009$ & $0.028 \pm 0.001$ & $0.023 \pm 0.001$ & $0.019 \pm 0.002$ & $0.014 \pm 0.000$ \\
Week 7 & $0.043 \pm 0.009$ & $0.019 \pm 0.002$ & $0.017 \pm 0.001$ & $0.012 \pm 0.001$ & $0.008 \pm 0.002$ \\
\hline
\end{tabular}

Comment on Why same values were for the control at the different times of Application: The control results are same for all the weeks because nothing was added to the control and the samples were obtained the same time (that is, 9th week) after the germination of the seeds. The standard error values for the shoot lengths of the crops treated with 15 and $20 \mathrm{ml}$ of spent oil are correct. The high error values are because each treatment was replicated thrice and result for one of the replicates was very low compared with other two replicates. Same reason goes for the high error values in the leaf area results.

plants treated with $15 \mathrm{ml}$ spent oil was significantly lower than that of the plant treated with $5 \mathrm{ml}$ of spent oil week one after germination $(\mathrm{P}<0.01)$. The dry matter content of maize treated with $20 \mathrm{ml}$ spent oil was also significantly lower than the dry matter of the plants treated with $5 \mathrm{ml}$ of spent oil at the 3rd, 5th and 7th weeks of application $(\mathrm{P}<0.05 ; \mathrm{P}<0.01)$.

The leaf areas of the plants treated with low levels of spent oil are higher than the leaf areas of the plants treated with higher levels of spent oil (Table 3). Statistical differences exist among the leaf areas of the plants treated at different times. The leaf areas of maize treated with $15 \mathrm{ml}$ spent oil at the first, third and seventh weeks of growth were significantly smaller than the leaf area of the plant not treated with spent oil $(\mathrm{P}<0.001 ; \mathrm{P}<0.05$ and $P<0.01)$ respectively. At the same times of application of spent oil, similar smaller leaves were noticed in plants treated with $20 \mathrm{ml}$ spent oil than in plant not treated with spent oil $(P<0.001 ; P<0.01)$ (Table 4). Treating the plants with $15 \mathrm{ml}$ spent oil and $20 \mathrm{ml}$ spent produced greater impacts on the leaf area of the plant than treating the plant with $5 \mathrm{ml}$ spent oil $(\mathrm{P}<0.05$ and $\mathrm{P}<0.01)$ respectively.

The chlorophyll of the maize plant generally decreased with the increase in the amount of spent oil added to the soil. While the $5 \mathrm{ml}$ treatment led to significant reduction of the chlorophyll content on at the first week of application $(\mathrm{P}<0.01)$, the chlorophyll content of the plant treated with $10 \mathrm{ml}$ spent oil at the first and third weeks of growth was significantly lower than that of the plants from the control treatment $(P<0.05 ; P<0.01)$. Treating the plant with $15 \mathrm{ml}$ spent oil at the first, fifth and seventh weeks of growth significantly reduced the chlorophyll content of the plant $(\mathrm{P}<0.01 ; \mathrm{P}<0.001)$. At the same level of significance, treatment of the plants with $20 \mathrm{ml}$ spent oil at all the weeks of application led to significant reduction of the chlorophyll content of the plant. The chlorophyll content of the plant treated with $20 \mathrm{ml}$ spent oil was also significantly lower than that of the plant treated with $5 \mathrm{ml}$ spent oil at the third week $(\mathrm{P}<0.01)$ and the chlorophyll content of the plant treated with $10 \mathrm{ml}$ oil at the first week of growth $(P<0.01)$. The chlorophyll contents of the plants treated at the fifth and seventh weeks were more closely related than the chlorophyll of the plants treated on the 
other weeks.

\section{DISCUSSION}

The reduction of the plant growth observed in this study could be due to reduction of mineral element with increasing oil concentration in the soil reported by Odjegba and Atebe (2007). This could have occurred as a result of reduced availability of mineral elements because according to Clarkson and Hanson (1980), plant nutrition is based not only on the presence of mineral elements in the soil but their availability. Another possible cause of the effects of spent oil on the maize plant observed in this study could be due to either the increased acidity in the soil or reduction in the catalase activity reported by Achuba and Peretiemo-Clark (2007). Such increase soil acidity can affect the microbial distribution in the soil reducing their activities in the rhizosphere. The reduction of the catalase activity can affect the optimal soil conditions required for plant growth hence the reduction of plant growth observed in this study.

According to Meinz (1999), spent oil contains heavy metals and polycyclic aromatic hydrocarbons and chemical additives including amines, phenols, benzenes, calcium, zinc, lead, barium, manganese, phosphorus and sulphur which are dangerous to living organisms. The high level of toxic heavy metals and polycyclic aromatic hydrocarbon which has been reported to be present in spent oil can also account for the growth inhibition observed in this study.

The reduction of the chlorophyll content of the plant could be due to the interference of the oil on the ability of the plant to absorb some of the mineral nutrients. Minerals like magnesium, iron, boron, and manganese are essential for chlorophyll synthesis (Campbell, 1996; Taylor et al., 1997; Kent, 2000). Such interference and the reduced rate of photosynthesis which accompanies reduction of chlorophyll can lead to plant death and stunted growth. Also the reduced leaf areas of the plants due to the addition of the spent oil can aggravate the photosynthesis level in the plant with resultant poor performance of the plant. All these can lead to low yield of the plant and low availability of food. The lower performance of the plants treated with spent oil at the first week of growth indicates that the plant has less resistant to pollution by spent at tender age than when it grows older. This is similar to the observation of Agbogidi et al. (2007) who observed more adverse effects on maize exposed to crude oil pollution at tender stage than at later stage. The greater impact of the spent oil on the tender plants indicates that the tender tissues are more susceptible to injurious effects possibly due to severe disintegration of the cell in soft basal stem segment of the plant. This is similar to the findings of Baker (1970) and Anoliefo (1998). This suggests that apart from the level of pollution, the age of plant has much influence on the survival of plants to oil pollution. As suggested by Agbogidi et al. (2007) the higher resistance of the older plants to the spent oil pollution may be due to the presence of already cutinised tissues in such plants.

In conclusion, from the results obtained in this study, it is advised here that to reduce loss of plant due to oil pollution, plants should not be exposed to oil pollution when they are at the tender stages. Also there should be stricter measures on indiscriminate disposal of spent oil in the environment particularly farmlands as this will reduce the yield of crops affected by indiscriminate disposal of petroleum products pollution to the environment.

\section{REFERENCES}

Achuba FI, Peretiemo-Clarke BO (2007). Effect of spent oil on soil catalase and dehydrogenase activities, Inter. Agrophy., 22: 1-4.

Adenipekun CO, Oyetunji OJ, Kassin LS (2008). Effect of spent engine oil on the growth parameters and chlorophyll content of Corchorus olitorius Linn. Environ., 28: 446-450.

Akinola MO, Udo AS, Okwok N (2004). Effect of crude oil (Bonny Light) on germination, early seedling growth and pigment content in maize (Zea mays L.) J. Sci., Technol. Environ., 4(1 and 2): 6-9.

Akoachere JTK, Akenji TN, Yongabi FN, Nkwelang G, Ndip RN (2008) .Lubricating oil-degrading bacteria in soils from filling stations and auto-mechanic workshops in Buea, Cameroon: Occurrence and characteristics of isolates. Afr. J. Biotechnol., 7(11): 1700-1707.

Andrade ML, Covelo EF, Vega FA, Marcet P (2004). Effect of the Prestige Oil spill on salt marsh soils on the coast of Galicia (Northwestern Spain). J. Environ. Qual., 33: 2103 - 2110.

Agbogidi OM, Eruotor PG, Akparobi SO (2007) Effects of Time Application of Crude Oil to Soil on the growth of Maize. Res. J. Environ. Toxicol., 1(3): 116-123.

Anoliefo GO (1998). Effects of spent lubricating oil on plant life. Infotech Today, October.

Anoliefo GO, Edegai BO (2000). Effects of spent oil as oil contaminant on the growth of two eggplant species Solanium melongena and $S$. incanum. J. Agric., For. Fish., 1:21-25.

ATSDR (Agency for Toxic Substances and Disease Registry) (1997) Toxicology profile for used mineral based crankcase oil. Department of Health and Human Services, Public Health Service Press, Atlanta, GA, USA.

Baker JM (1970). The effects of oil on plant physiology. In: The ecological effects of oil pollution on littoral communities. Cowell EB (Ed). Applied Science Publishers, London, pp. 88-98.

Campbell NA (1996). Biology $4^{\text {th }}$ edn, The Benjamin/Cummings Publishing Company Inc., California, p. 1206.

Clarkson DT, Hanson JB (1980). The mineral nutrition of higher plant. Ann Rev Plant Physiol., 31: 239-298.

Dominguez-Rosado RE, Pichtel J (2004). Phytoremediation of soil contaminated with used motor oil. 1. Enhanced microbial activities from laboratory and growth chamber studies. Environ. Engr. Sci., 2: 157-168.

Heidcamp W (2003). Handbook on determination of chlorophyll content in spinach leaves, p. 1.

Inoni OE, Omotor DG, Adun FN (2006). The effect of oil spillage on crop yield and farm income in Delta State, Nigeria. J. Centr. Eur. Agric., $7(1): 41-49$

Kent M (2000). Advanced Biology, Oxford University Press, UK, p. 623. Meinz V (1999). Used oil characterization study. Washington State Department of ecology solid and hazardous waste program, p. 19. www.ecy.wa.gov/ biblio/ 91052.html.

Merkl N, Schultze-Kraft R, Infante C (2004). Phytoremediation in the Tropics. The Effect of Crude Oil on the Growth of Tropical Plants. Bioremed. J. 8: 177-184. 
Nicolotti G, Egli S (1998). Soil contamination by crude oil: Impact on the mycorhizosphere and on the revegetation potential of forest trees. Environ. Poll., 99: 37-43.

Odjegba VJ, Sadiq AO (2002) Effect of spent engine oil on the growth parameters, chlorophyll and protein levels of Amaranthus hybridus L.. Environ., 22: 23-28.

Odjegba VJ, Atebe JO (2007). the effect of used engine oil on carbohydrate, mineral content and nitrate reductase activity of leafy vegetable (Amaranthus hybridus L.). J. App. Sci. Environ. Manage., 11(2): 191-196.

Olugboji OA, Ogunwole OA (2008). Use of spent engine oil. AU J.T. 12(1): 67-71.

Osubor CC, Anoliefo GO (2003). Inhibitory effects of spent lubricating oil on the growth and respiratory functions of Arachis hypogea L. Benin Sci. Dig, 1: 73-79.

Renault S, Zwlazek JJ, Fung M, Tuttle S (2000). Germination, growth and gas exchange of selected boreal forest seedlings in soil containing oil sands tailing. Environ. Poll., 107: 357-365.

Sharifi M, Sadeghi Y, Akbarpour M (2007). Germination and growth of six plant species on contaminated soil with spent oil. Inter. J. Environ., Sci. Technol., 4(4): 463-470.
Siddiqui S, Adams WA (2002). The fate of diesel hydrocarbons in soils and their effects on germination of perennial ryegrass. Environ. Toxicol., 17(1): 49-62.

Taylor DJ, Green NPO, Stout R (2001). Biological Science 1\&2, $3^{\text {rd }}$ edn., Cambridge University Press, p. 984.

Pearcy RW, Ehleringer JR, Mooney H, Rundel PW (1989). Plant physiological ecology: Field methods and instrumentation. Chapman and Hall, New York, pp. 301-306.

Vwioko DE, Fashemi DS (2005). Growth Response of Ricinus communis L. (Castor Oil) in Spent Lubricating Oil Polluted soil. J. App. Sci. Environ. Manage., 9(2): 73-79.

Wang J, Jia CR, Wong CK, Wong PK (2000). Characterization of polycyclic aromatic hydrocarbon created in lubricating oils. Water, Air Soil Poll., 120: 381-396. 